\title{
To Cheat or Not to Cheat?: The Role of Personality in Academic and Business Ethics
}

\section{Authors: Virginia K. Bratton \& Connie Strittmatter}

This is an Accepted Manuscript of an article published in Ethics \& Behavior on November 2013, available online: http://www.tandfonline.com/10.1080/10508422.2013.811077.

Bratton, Virginia K., and Connie Strittmatter. "To Cheat or Not to Cheat?: The Role of Personality in Academic and Business Ethics." Ethics \& Behavior 23, no. 6 (November 2013): 427-444. doi:10.1080/10508422.2013.811077.

Made available through Montana State University's $\underline{\text { ScholarWorks }}$ 


\title{
To Cheat or Not to Cheat?: The Role of Personality in Academic and Business Ethics
}

\author{
Virginia K. Bratton \\ Connie Strittmatter \\ QUERY SHEET
}

This page lists questions we have about your paper. The numbers displayed at left can be found in the text of the paper for reference. In addition, please review your paper as a whole for correctness.

Q1: Au: Please add reference for Megehee (2008) or delete citation.

Q2: Au: Elias and Kim (2004) does not have a matching reference. Provide reference or remove citation.

Q3: $\quad$ Au: Jackson, Furnham, Levine, and Burr (2002) is not in the reference list. Add reference or remove citation.

Q4: $\quad$ Au: Brown, Sautter, Littvay, \& Bearnes (2010) is not in the reference list. Add reference or remove citation.

Q5: $\quad$ Au: Sautter, Brown, Littvay, \& Bearnes (2008) is not in the reference list. Add reference or remove citation.

Q6: Au: Please ensure that the trait names begin with capital letters when used in the article.

Q7: $\quad$ Au: This O'Connor \& Paunonen (2011) citation is listed in the references as 2007; please adjust where necessary.

Q8: $\quad \mathrm{Au}$ : Rest (1994) is not in the reference list. Add reference or remove citations.

Q9: Au: Karim et al. (2007) is not in the reference list. Add reference or remove citation.

Q10: $\quad A u$ : Nonis and Swift (2003) is not in the reference list. Add reference or remove citation.

Q11: Au: Elias and Kim (2004): Add reference or remove citation.

Q12: Au: Please change "females" to "women" unless there were girls/adolescents in the group with adults.

Q13: $\quad$ Au: Should $\rho$ be $\mathrm{p}$ in this paragraph?

Q14: $\quad$ Au: Nonis and Swift (2002): Please add 2002 reference.

Q15: $\quad$ Au: Elias and Kim (2004): Please provide this reference.

Q16: $\quad$ Au: Nonis and Swift (2001): Please provide a 2001 reference.

Q17: $\quad$ Au: Brown et al. (2010) does not have a citation in text; please add citation or delete reference.

Q18: Au: Elias and Kim (2005) does not have a matching text citation; please add citation or delete reference. 
Q19: $\quad \mathrm{Au}$ : Flory et al. does not have a citation in text; please add citation or delete reference.

Q20: $\quad$ Au: Megehee and Spake does not have a matching text citation; please add citation or delete reference.

Q21: $\quad \mathrm{Au}$ : O'Connor and Paunonen (2007) does not have a matching text citation; please add citation or delete reference.

Q22: $\quad \mathrm{Au}$ : Rest and Narvaez does not have a citation in text; please add citation or delete reference.

Q23: $\quad \mathrm{Au}$ : Sautter et al. does not have a citation in text; please add citation or delete reference.

Q24: $\quad \mathrm{Au}$ : Shi et al. does not have a citation in text; please add citation or delete reference.

\section{TABLE OF CONTENTS LISTING}

The table of contents for the journal will list your paper exactly as it appears below:

To Cheat or Not to Cheat?: The Role of Personality in Academic and Business Ethics Virginia K. Bratton and Connie Strittmatter 


\title{
To Cheat or Not to Cheat?: The Role of Personality in Academic and Business Ethics
}

\author{
Virginia K. Bratton \\ College of Business \\ Montana State University \\ Connie Strittmatter \\ Montana State University Library
}

\begin{abstract}
Past research (Lawson, 2004; Nonis \& Swift, 2001) has revealed a correlation between academic and business ethics. Using a sample survey, this study extends this inquiry by examining the role of dispositional variables (neuroticism, extraversion, and conscientiousness) and academic honesty on business ethics perceptions. Results indicate that (1) neuroticism and conscientiousness were positively related to more ethical perceptions in a work context, and (2) academic honesty partially mediated the relationship between conscientiousness and business ethics. Implications to business practitioners and educators are discussed as well as directions for future research.
\end{abstract}

Keywords: academic dishonesty, academic ethics, plagiarism ethics, business ethics, workplace ethics, professional ethics, academic etiquette, student ethics, big five personality neuroticism, extraversion, conscientiousness

\section{INTRODUCTION}

In recent years, attempts have been made to understand the motivating factors for ethical behavior. From the actions of Enron in the early 2000s to the demise of the housing market and ultimate economic recession beginning in 2007, business ethics has been at the forefront of not only the news but also the academic literature. Business schools have revamped their ethics curricula in hopes of sending more ethical students into the workplace. However, questions have arisen from recent research (Bloodgood, Turnley, \& Mudrack, 2010; Waples, Antes, Murphy, Connelly, \& Mumford, 2009) as to whether teaching ethics in the classroom is effective in changing or improving ethical tendencies among business students and future business practitioners. At the same time, researchers have continued their efforts to understand the characteristics of ethical people yielding mixed results (Collins, 2000; Ford \& Richardson, 1994; Loe, Ferrell, \& Mansfield, 2000). What roles do demographic and personality traits and scholastic or intellectual aptitude play in the development of ethical character?

Correspondence should be addressed to Virginia K. Bratton, Management, College of Business, Montana State University, Bozeman, MT 59717. E-mail: vbratton@montana.edu 
These same questions have driven investigations into academic honesty. Numerous studies have been conducted to determine who is likely to cheat or plagiarize during their academic career, why and how they do it (McCabe, Butterfield, \& Trevino, 2006; Meade, 1992; Megehee, 2008; Park, 2003; Pullen, Ortloff, Casey, \& Payne, 2000; Rakovski \& Levy, 2007; Smyth \& Davis, 2004). Much of this research is limited by assessments of unethical academic behavior with single-item measures, often developed on an ad hoc basis. Two exceptions include studies conducted by Jung (2009) and Yang (2012), both of which applied the Multidimensional Ethics Scale (MES), developed by Reidenbach and Robin (1990), to academic dishonesty scenarios.

Although research has shown that there is a link between academic honesty and future ethical behaviors in the workplace (Elias \& Kim, 2004; Lawson, 2004; Nonis \& Swift, 2003; Sims, 1993), the exact nature of this relationship and how individual factors influence this relationship are still unclear. These studies investigated whether grade point average (GPA), class rank, gender, and age are variables that affect an individual's propensity toward academic and workplace dishonesty. An area ripe for exploration is whether personality traits are a factor in determining a student's ethical attitudes toward academic and workplace behavior. Previous studies have investigated whether personality traits impact academic ethics and business ethics in isolation, but none to date have explored the relationship between personality traits and the link between academic and workplace ethics.

This study explores this line of investigation by examining antecedents to ethical behavior. Specifically, we draw on the theory of meaningful work (Barrick, Mount, \& Li, 2013) and the moral intensity construct (Jones, 1991) to inform an examination of salient individual characteristics that influence ethical decisions in both an academic and work context. The purpose of this study is to further explore the personality characteristics of the decision maker in ethical situations and the relationships between perceptions of academic and business ethical behavior. Toward this end, we examine student perceptions of business and academic ethics using the Multidimensional Ethics Scale developed by Reidenbach and Robin (1990). Following Jung (2009) and Yang (2012), we apply the MES to the context of academic honesty and seek to derive a valid assessment of student perceptions of ethics in an academic context as well as provide a clear empirical link to perceptions of business ethics. Furthermore, we attempt to clarify the mixed results from previous work (Jackson, Furnham, Levine, \& Burr, 2002; Karim, Zamzuri, \& Nor, 2009; Moberg, 1999; Williams, Nathanson, \& Paulhus, 2010) that has examined extraversion, neuroticism, and conscientiousness, three of the NEO Five Factor Personality (Big 5) dimensions (Costa \& McCrae, 1992), and their impact on academic and business ethics.

\section{LITERATURE REVIEW}

Several individual factors have been examined in relation to business ethics as well as academic honesty. Although much research has been done in past years exploring the impact of personality variables such as locus of control (Forte, 2005; Hegarty \& Sims, 1978; Hume \& Smith, 2006), Machiavellianism (Mudrack \& Mason, 1995; Tang \& Chen, 2008; Williams et al., 2010), narcissism (Brown, Sautter, Littvay, \& Bearnes, 2010; Sautter, Brown, Littvay, \& Bearnes, 2008; Williams et al., 2010), empathy (Brown et al., 2010; Detert, Treviño, \& Sweitzer, 2008; Sautter et al., 2008), and emotional intelligence (Angelidis \& Ibrahim, 2011; Joseph, Berry, \& Deshpande, 2009), relatively little research has explored the link between the Big 5 personality profile and ethics (Bratton, 2004). 
The NEO Five Factor Model of Personality ((Big 5) personality traits, is composed of Neuroticism, Extraversion, Agreeableness, Conscientiousness, and Openness to Experience. The Big 5 personality profile has been one of the most studied personality profiles in management research (Perrewé \& Spector, 2002). These personality traits have been used in business settings to determine career success and choice (Reed, Bruch, \& Haase, 2004; Seibert \& Kraimer, 2001), leadership style (Bono \& Judge, 2000), job satisfaction (Judge, Heller, \& Mount, 2002), and organizational citizenship behavior (Kumar, Bakhshi, \& Rani, 2009; Organ, 1994). The Big 5 also has been identified as a factor in academic achievement (Atashrouz, Pakdaman, \& Asgari, 2008; de Feyter, Caers, Vigna, \& Berings, 2012; O’Connor \& Paunonen, 2011), learning styles (Busato, Prins, Elshout, \& Hamaker, 1999; Komarraju, Karau, Schmeck, \& Avdic, 2011; Zhang, 2003), and academic motivation (Clark \& Schroth, 2010; Komarraju \& Karau, 2005). However, there are few examples of research that apply the Big 5 to academic honesty or business ethics (Williams et al., 2010). In this research, we examine the Big 5 personality profile and the impact of three of its dimensions (neuroticism, extraversion and conscientiousness) on ethics.

Figure 1 displays our proposed theoretical model. This model highlights Neuroticism and Extraversion (from a cognitive trait emotion approach) as influential personality traits in the moral deliberation process because of the need to arouse an emotional response in order to trigger ethical decision making (Rest, 1986, 1994). Our theoretical model also highlights conscientiousness as a key variable in moral deliberation because of the importance of strength of mind and commitment to consider alternatives, identify the correct action, and formulate the intent to implement that action (Rest, 1986, 1994). Therefore, we limit our application of the Big 5 personality profile to dimensions that will impact the moral deliberation of individuals in recognizing ethical dilemmas and forming ethical perceptions in academic and business situations. Furthermore, drawing on the theory of meaningful work (Barrick et al., 2013), as well as the moral intensity construct (Jones, 1991), we hypothesize that academic ethics perceptions will mediate the relationship between personality and business ethics. Each of these key relationships is discussed next with proposed hypotheses.

\section{Neuroticism}

Neuroticism is related to emotion, specifically negative emotion. Those with high neuroticism are more prone to stress and are less adaptive when dealing with difficult situations (Costa \& McCrae, 1992). The facets that compose Neuroticism are anxiety (levels of stress and worry), angry

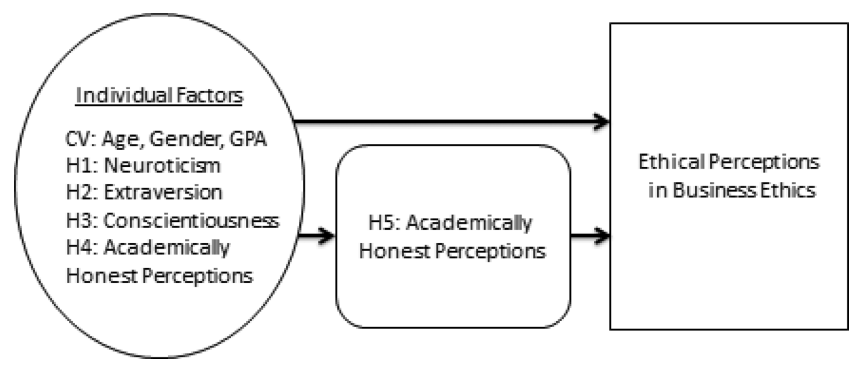

FIGURE 1 Academic perceptions as a mediator between individual factors and business ethics. Note. GPA = grade point average. 
hostility (susceptibility to experience anger), depression (feelings of sadness and loneliness), self105 consciousness (levels of shame and embarrassment), impulsiveness (inability to control urges), and vulnerability (ability to cope with stress; Piedmont, 1998). Neuroticism is often associated with negative trait affect (Gale, Edwards, Morris, Moore, \& Forrester, 2001). Because individuals who are highly neurotic tend to be less confident and prone to higher levels of stress, their motivation for unethical behavior may result more in their desire to avoid failure than to achieve success (Barrick et al., 2013).

Neurotic behavior can manifest itself in a variety of workplace settings. Kets de Vries (1984) identified five neurotic management styles that impact organizations and its employees. High levels of neuroticism in supervisors in conjunction with perceived levels of high stress and low conscientiousness, has led to increased employee perceptions of workplace bullying (Mathisen, Einarsen, \& Mykletun, 2011). Interpersonal and workplace deviance has a strong relationship with high levels of neuroticism (Berry, Ones, \& Sackett, 2007). Although Xu, Yu, and Shi (2011) found high levels of neuroticism to be negatively related to ethical leadership, the literature that examined the relationship between neuroticism and ethical behavior in academia has produced inconsistent results. In academic settings, Jackson, Levine, Furnham, and Burr (2002) found that high neuroticism predicted cheating behaviors. In contrast, some studies have found that neuroticism was not significant in self-reported cheating (Nathanson, Paulhus, \& Williams, 2006; Williams et al., 2010). However, Karim et al. (2007) found evidence to support the relationship between neuroticism and Internet ethics.

Neurotics often have high levels of anxiety, which may make them more aware of the consequences of their actions. This may be because neuroticism, like negative affectivity, can cause in individuals a heightened sensitivity to cues relating to punishment and frustration (Gray, 1990, 1994). Whereas, on the one hand, neurotic individuals are anxious and not resilient to stress (Williams et al., 2010), they also are aware of the potential consequences of their behavior in any given setting. In this study, we focus on the hostility, anxiety, and depression facets of neuroticism and expect that students who are highly neurotic will be more likely to experience high levels of emotional arousal upon perceiving an ethical situation. This will lead them to become easily frustrated and less able to engage in the complex cognitive processes (Forgas, 2001; Larsen, 2000) that are necessary in successful moral deliberation. Thus, we expect that students that possess high levels of neuroticism will be less able to form ethical business perceptions and propose the following hypothesis:

H1: Neuroticism is negatively related to ethical perceptions.

\section{Extraversion}

Extraversion is related to an individual's desire for interpersonal interaction, stimulation, and capacity for happiness (Costa \& McCrae, 1992). It has also been linked to positive trait affect (Larsen \& Ketelaar, 1989). Extroverts draw energy from interacting with others and are action oriented. The facets associated with extraversion are warmth (propensity toward intimacy), gregariousness (desire to participate in groups), assertiveness (levels of dominant and forceful behavior), activity (energy levels), excitement seeking (need for stimulation), and positive emotions (tendency to experience emotions such as joy, love, and excitement; Piedmont, 1998). 
Extroverts tend to experience positive emotions and may be more likely to engage in the complex cognitive processes required to make ethical decisions (Bratton, 2004). The research that has examined the relationship between extraversion and ethics has been equivocal. Cizek (1999) found in three out of four studies that extraversion did have some effect on cheating behaviors. However, Jackson et al. (2002) found that extroversion was not a predictor of unethical academic behavior. This is consistent with results produced by Williams et al. (2010), where extraversion produced no significant impact on self-reported cheating as well as Karim et al. (2009) where results also indicated no significant relationship between extraversion and Internet ethics.

Although recent studies have suggested that extraversion is not related to ethical perceptions, we draw upon the positive emotions facet of this trait and expect students who are highly extroverted will be more likely to experience emotional arousal upon perceiving an ethical situation. This emotional arousal within extroverted individuals will result in the engagement of cognitive processes (Forgas, 2001; Larsen, 2000) that are necessary to facilitate moral deliberation (Bratton, 2004). Therefore we hypothesize the following:

$\mathrm{H} 2$ : Extraversion is positively related to ethical perceptions.

\section{Conscientiousness}

Those who score high on conscientiousness tend to be self-disciplined, exert control, and are very deliberate in their actions (Costa \& McCrae, 1992). Facets that compose conscientiousness include competence (levels of sensibilities and effectiveness), order (levels of organization and tidiness), dutifulness (ability to adhere to ethical principles), achievement striving (goal-oriented), self-discipline (ability to complete tasks), and deliberation (carefully thinking before acting; Piedmont, 1998).

The literature consistently has indicated positive relationships between conscientiousness and ethics across both academic and workplace contexts. For example, Karim et al. (2009) found a positive relationship between conscientiousness and Internet ethics. Conscientiousness was also found to be negatively correlated to academic dishonesty in a study surveying 683 psychology students (de Bruin \& Rudnick, 2007). Williams et al. (2010) also found high conscientiousness to be negatively correlated with self-reported cheating. These studies are consistent with additional research that investigated the relationship between conscientiousness and academic ethics (Emler, 1999; Kisamore, Stone, \& Jawahar, 2007; Murphy, 2000). This research suggests that individuals who score low on conscientiousness are often less prepared and less organized, tend to procrastinate, and lack motivation and ambition, which results in an increased propensity toward cheating. Furthermore Higgins, Peterson, Pihl, and Lee (2007) indicated a significant relationship between highly conscientious individuals and academic and workplace performance.

In the workplace context, conscientiousness is related to ethical leadership (Kalshoven, Den Hartog, \& De Hoogh, 2011). Hogan and Hogan (1989) found conscientiousness to be related to employee reliability. Highly conscientious individuals are "organized, reliable, hardworking, determined, self-disciplined, [and] rule abiding" in addition to being driven to achieve goals (Barrick et al., 2013, p. 145). These facets, and specifically rule-abiding (dutifulness), suggest that conscientious individuals "adhere strictly to their ethical principles and scrupulously fulfill their moral obligations" (Piedmont, 1998, p. 91). 
Conscientiousness also can lessen or diminish negative perceptions. Hochwarter, Witt, and Kacmar (2000) found this to be true when they studied the perceptions of politics on job performance. Bratton's (2004) research extended this stream of research by studying whether higher levels of conscientiousness served as a buffer against the effect of external obstacles that interfere with one's moral intentions versus one's moral behavior. Following this line of research, we expect that highly conscientious students will be more aware of the elements of a situation that require an ethical decision to be made, and hence, more likely to arrive at ethical conclusions. Following this logic, the following hypothesis is proposed:

H3: Conscientiousness is positively related to ethical perceptions.

\section{Academic Honesty Versus Business Ethics: Once a Cheater, Always a Cheater?}

Is unethical workplace behavior an extension of unethical academic behavior displayed in higher education? Several studies have indicated a positive relationship between academic and work place dishonesty. Sims (1993) conducted one of the first studies in this area and found that students who participated in unethical behavior in an academic setting were also likely to participate in unethical workplace activities. Nonis and Swift (2003) expanded on Sims's study by examining a larger sample of students from multiple universities. They confirmed a high correlation between cheating behaviors in academic and workplace settings. Other studies (Elias \& Kim, 2004; Lawson, 2004) have produced results to support this relationship. As Ajzen (1991) emphasized in developing his theory of planned behavior that "the best predictor of future behavior is past behavior." Keeping this in mind, we expect the following:

H4: Ethical academic perceptions is positively related to workplace ethical perceptions.

With so many demographic, personality, and behavioral traits affecting ethical behavior, is there one characteristic that outweighs the others? Given that past studies have found such strong and statistically significant relationships between academic and workplace integrity, it can be argued that academic honesty is a defining element in the relationship between individual factors and business ethics. Barrick et al. (2013) theorized that it is the perception of meaningfulness of one's actions that provides the link between personality and work outcomes. Hackman and Oldham (1975) suggested that experienced meaningfulness is the most important mediator between the characteristics of work and its outcomes. Drawing on this work, we theorize that the context of academic honesty may provide a more meaningful ethical context in which students can morally deliberate. An academic moral dilemma provides to students an ethical situation that has greater temporal immediacy (students may discount the impact of events perceived to occur in the future) and closer proximity (feelings of nearness that students perceive to the act in question) which may make an ethical dilemma more meaningful to students due to a perceived increase in moral intensity (Jones, 1991). As found by Singhapakdi, Vitell, and Franke (1999), perceived moral intensity can mediate the relationship between personality and perceptions of ethical problems. We assert that the professional nature of the business ethics dilemmas may seem distant to students who have yet to enter their professional careers. As a result, students may perceive the business ethics scenarios to be less meaningful, which may produce "noise" in the relationship between personality and ethical workplace perceptions. Therefore, we expect academic honesty to mediate the relationship between personality and ethical perceptions in the workplace. 
H5: Ethical academic perceptions will mediate the relationship between ethical workplace perceptions and individuals' levels of neuroticism, extroversion, and conscientiousness.

\section{METHOD}

\section{Sample}

A total of 293 (response rate $=20 \%$ ) students enrolled in business classes at a university in the northwest region of the United States responded to a survey distributed online from September to November 2010. Of those who provided demographic information, $50.9 \%$ were men, $49.1 \%$ were females, $93.2 \%$ were U.S. residents, the average age was 20.75 years, $30 \%$ were freshmen, $34.5 \%$ were sophomores, and $23.9 \%$ were juniors, and $63.5 \%$ of respondents were business majors.

\section{Procedure}

E-mails were distributed to participating classes (multiple sections of a 100-, 200-, and 300-level core business classes), which included a letter written by the researchers and class instructor as well as the web address of the survey. The letters stressed accuracy and timeliness in completing the surveys and assured anonymity. In an effort to solicit as many responses as possible, extra credit points were offered to students who completed the survey. Also, a lottery drawing for a $\$ 50$ campus bookstore gift certificate served as an inducement for students to complete the survey.

\section{Measures}

Business ethics. Attitudes and perceptions of business ethics were measured using Reidenbach and Robin's (1990) MES. The MES has proven successful in many empirical studies, which is why this scale was selected for this study. Reidenbach and Robin initially developed three business scenarios for MES. Throughout the years, additional scenarios have been added ranging from tax (Cruz, Shafer, \& Strawser, 2000), to tourism (Hudson \& Miller, 2005), to information ethics (Jung, 2009). In the current study, this scale presented two business scenarios derived from tools developed by DuPont and Craig (1996) and Robin and Babin (1997). After each scenario, eight items assessed each respondent's business ethical judgments. The items were scored on a 4-point Likert scale from 1 (strongly disagree) to 4 (strongly agree). Sample items include "This action violates an unspoken promise" and "The action taken was fair" (reverse coded). The maximum possible score for each scenario is 32 points, which indicates highly moral judgments. See Appendix A for a sample business ethics scenario used in this survey.

Academic honesty. Past research in academic honesty has relied on scenarios with a handful of follow-up questions (Yeo, 2007). With few exceptions (Jung, 2009; Yang, 2012), academic honesty scenarios have not been coupled with the MES approach of Reidenbach and Robin (1990). In this study we measured perceptions of academic honesty by using two plagiarism scenarios adapted from Barrett and Cox (2005) and from Yeo (2007). Similar to our measure of business ethics, each scenario is followed by eight items that evaluate the ethical judgments of 
respondents in an academic context with a maximum possible score of 32 to indicate individuals with highly moral judgments. See Appendix B for a sample academic honesty scenario used in this survey.

Neuroticism, extraversion, and conscientiousness. Each of these constructs is a dimension of the NEO Five Factor Inventory (Costa \& McCrae, 1992). They are each measured by a 12-item subscale that is scored on a 4-point Likert scale from 1 (strongly disagree) to 4 (strongly agree). Neuroticism relates to an individual's negative feelings whereas extraversion concerns an individual's facets of ambition and sociability (Hogan \& Hogan, 1989). Conscientious individuals are thought to be reliable, structured, assiduous, and persistent (Barrick \& Mount, 1991). A sample item from the neuroticism scale is "I am not a worrier" (reverse coded). The Extraversion scale includes items such as "I enjoy talking to people." "I waste a lot of time before settling down to work" (reverse coded) is a sample item from the Conscientiousness scale. ${ }^{1}$ Scales were computed additively so a maximum potential score of 48 would indicate high levels in each characteristic.

Control variables. In keeping with past research, which has examined the impact of numerous other demographic factors on individual ethical attitudes in academia and the workplace, subjects were asked to indicate their age, gender (male $=1$; female $=2$ ), and GPA.

\section{RESULTS}

Table 1 presents descriptive statistics, correlations, and Cronbach's alpha(s) (internal reliability estimates) for variables. As shown there, Business and Academic Ethics perceptions were positively related at $.297(p<.01)$, which suggests that these constructs are related but conceptually distinct and allows us to proceed with our analysis treating these as two separate constructs. Also

TABLE 1

Intercorrelation Matrix

\begin{tabular}{|c|c|c|c|c|c|c|c|c|c|}
\hline Variable & M & SD & 1 & 2 & 3 & 4 & 5 & 6 & 7 \\
\hline 1. Business Ethics & 23.44 & 4.60 & $(.80)$ & & & & & & \\
\hline 2. Age & 20.75 & 4.12 & .019 & - & & & & & \\
\hline $\begin{array}{l}\text { 3. Gender }(1=\text { male, } \\
2=\text { female })\end{array}$ & 1.48 & 0.51 & $.164^{* *}$ & -.032 & - & & & & \\
\hline 4. GPA & 3.21 & 1.56 & -.071 & .098 & -.040 & 一 & & & \\
\hline 5. Neuroticism & 25.30 & 5.80 & .047 & .073 & $.136^{*}$ & .033 & $(.78)$ & & \\
\hline 6. Extraversion & 35.75 & 5.13 & $.160^{* *}$ & -.100 & $.236^{* *}$ & .017 & $-.318^{* *}$ & $(.77)$ & \\
\hline 7. Conscientiousness & 37.38 & 5.35 & $.223^{* *}$ & .002 & $.245^{* *}$ & $.228^{* *}$ & $*-205^{* *}$ & $.347^{* *}$ & $(.83)$ \\
\hline 8. Academic Honesty & 23.86 & 4.73 & $.297^{* *}$ & -.092 & $.222^{* *}$ & .034 & -.072 & $.129^{*}$ & $.244^{* *}$ \\
\hline
\end{tabular}

Note. $N=293$. Cronbach alphas are reported on the diagonal.

${ }^{*} p<.05 .{ }^{* *} p<.01$.

\footnotetext{
${ }^{1}$ Reproduced by special permission of the Publisher, Psychological Assessment Resources, Inc., 16204 North Florida Avenue, Lutz, Florida 33549, from the NEO Five-Factor Inventory by Paul Costa and Robert McCrae, Copyright 1978, 1985, 1989, 1991, 2003 by PAR, Inc. Further reproduction is prohibited without permission of PAR, Inc.
} 
shown in Table 1, extraversion was positively related to business ethics indicating initial support for Hypothesis 2. Hypothesis 3, that conscientiousness and business ethics would be positively related, also received initial support. Finally, academic honesty was positively related to business ethics, which offered preliminary support for Hypothesis 4.

Our measure of Business and Academic ethics (the MES) was designed to capture three underlying dimensions of ethical deliberation: moral equity, relativism, and contractualism (Reidenbach \& Robin, 1990). We conducted a factor analysis to examine the dimensionality of this scale with this data. The results indicated that all eight items loaded overwhelmingly onto one factor (which explained $42.7 \%$ of the variance observed among the Business Ethics items and $53.2 \%$ of the variance observed among the Academic Honesty items). Due to these results, we treat both Business Ethics and Academic Honesty as single-dimension constructs moving forward in our analyses.

We conducted hierarchical regression analysis to test Hypotheses 1 to 4 . The results of this analysis are presented in Table 2. In Step 1, the control variables (age, gender, and GPA) were entered. In Step 2, neuroticism, extraversion, and conscientiousness were entered into the equation. Finally in Step 3, academic honesty was entered into the equation. Based on the results elicited in Steps 2 through 3, Hypothesis 1, neuroticism was negatively related to business ethics, was not supported. Although the relationship between neuroticism and business ethics was statistically significant, this analysis revealed it to be positively related to business ethics in this study. Hypothesis 2, that extraversion was positively related to business ethics, was not supported. Hypothesis 3, that conscientiousness was positively related to business ethics, was supported by the results elicited in Step 2 of the regression analysis. Finally, Hypothesis 4, that academic honesty was positively related to business ethics, was supported. When academic honesty was entered into the equation in Step 4, the beta weight of conscientiousness decreased, whereas the beta weight for neuroticism increased. This interesting effect suggests that academic honesty

TABLE 2

Hierarchical Regression Analyses of the Gender, Personality Variables, \& Academic Honesty on Business Ethics

\begin{tabular}{lcccc}
\hline Independent Variables & Step 1: $\beta$ & Step 2: $\beta$ & Step 3: $\beta$ & $\Delta \mathrm{R}^{2}$ \\
\hline Step 1: Control Variable & & & & $.03^{*}$ \\
$\quad$ Age & .04 & .04 & .06 & \\
$\quad$ Gender & $1.45^{* *}$ & .55 & .134 & \\
$\quad$ GPA & -.20 & $-.38^{*}$ & $-.39^{*}$ & \\
$F(3,289)=3.17^{*}$, Adjusted $R^{2}=.022$ & & & & $.09^{* * *}$ \\
Step 2: Main Effect & & & $.11^{*}$ & \\
$\quad$ Neuroticism & & $.10^{*}$ & .10 & \\
$\quad$ Extraversion & $.19^{* *}$ & $.15^{* *}$ & \\
$\quad$ Conscientiousness & & & $.15^{* * *}$ \\
$F(6,286)=4.92^{* * *}$, Adjusted $R^{2}=.075$ & & & $.24^{* * *}$ & \\
Step 3: Main Effect & & & \\
$\quad$ Academic Honesty & & & & \\
$F(7,285)=7.34^{* * *}$, Adjusted $R^{2}=.132$ & & & & \\
\hline
\end{tabular}

Note. Standardized regression coefficients are presented. $N=293$.

${ }^{*} p<.1{ }^{* *} p<.01 .{ }^{* * *} p<.001$. 
TABLE 3

Regression Results for the Mediating Effect of Academic Honesty on the Relationship Between Individual Variables (Gender and Conscientiousness) and Ethical Behavior

\begin{tabular}{lllcrl}
\hline Equation & $\begin{array}{c}\text { Dependent } \\
\text { Variable }\end{array}$ & \multicolumn{1}{c}{$\begin{array}{c}\text { Independent } \\
\text { Variables }\end{array}$} & $\beta^{a}$ & $T$ & $\mathrm{R}^{2}{ }_{\text {adj }}$ \\
\hline 1. & Business Ethics & Conscientiousness & $.215^{* * *}$ & 4.007 & .068 \\
2. & Academic Honesty & Conscientiousness & $.165^{* *}$ & 3.020 & .082 \\
3. & Business Ethics & Conscientiousness & $.174^{* *}$ & 3.293 & .125 \\
& & Academic Honesty & $.249^{* * *}$ & 4.431 & \\
\hline
\end{tabular}

\footnotetext{
Note. $N=293$.

${ }^{\text {a }}$ Standardized regression coefficients.

${ }^{*} p<.1{ }^{* *} p<.01{ }^{* * *} p<.001$.
}

might play a mediating role in the relationship between conscientiousness (but not neuroticism or extraversion) and business ethics as suggested by Hypothesis 5 .

Baron and Kenny's (1986) test for mediation was used to analyze academic honesty as a mediator for the relationships between conscientiousness and business ethics. The results of this three-step process are reported in Table 3. In Step 1, the business ethics was regressed on conscientiousness and yielded significant results at a probability level of $.001(\beta=.215, \rho<$ $.001)$. In Step 2, academic honesty was regressed on conscientiousness, also yielding significant results (conscientiousness: $\beta=.165, \rho<.01$ ). In Step 3, business ethics was regressed on conscientiousness as well as academic honesty. Here, the beta weight of conscientiousness decreased (conscientiousness: $\beta=.174, \rho<.01$ ), whereas academic honesty also was significant $(\beta=.249, \rho<.001)$. Thus, this analysis provided evidence to support partial mediation. Thus, Hypothesis 5, which predicts academic honesty mediated the relationship between business ethics and neuroticism, extraversion, and conscientiousness, was partially supported. Academic ethics was found to partially mediate the relationship between business ethics and conscientiousness.

\section{DISCUSSION}

Research and practitioner interest in business ethics and the development of ethical conduct has sustained growth over the years. The proliferation of corporate ethical failures has certainly fueled this interest. But also, this interest may be due to the recognition of challenges in training and developing future practitioners in an academic setting. Research that highlights the mechanisms of situational and dispositional antecedents of ethical decision making may make a significant contribution toward improved corporate ethical conduct and support organizational goals.

The amount of attention devoted to ethical decision making in the business context as well as ethics training in an academic setting suggests that clarifying the relationship between ethics perceptions across these two contexts is vital. This study addresses this challenge by examining dispositional determinants of ethical behavior in business-emphasizing Big 5 traits that may 
factor into moral recognition, moral judgment, and moral character-and factoring in individual tendencies toward ethical behavior in an academic setting. As hypothesized, our findings support that an individual's ethical perceptions in academia tends to mediate the relationship between his and her personality, specifically conscientiousness, and perceptions of ethical behavior in a business setting.

Hypothesis 1, that neuroticism would be negatively related to business ethics, was not supported. In our sample, individuals with higher levels of neuroticism tended to form more ethical business perceptions than those with lower levels of this trait. Past research has found a consistent though weak negative correlation between neuroticism and cheating behavior (Cizek, 1999; Jackson et al., 2002; where highly neurotic individuals were found to be more likely to report cheating behavior or form less ethical perceptions). Thus it is surprising that the current study found a significant but reversed relationship between neuroticism and business ethics. This may be because neuroticism, like negative affectivity, can cause in individuals a heightened sensitivity to cues relating to punishment and frustration (Gray, 1990, 1994). Although, on one hand, neurotic individuals are anxious and not resilient to stress (Williams et al., 2010), they also are aware of the potential consequences of their behavior in any given setting. These two tendencies may have worked against each other in the current study, producing the unexpected observed positive relationship.

Hypothesis 2 predicts a positive relationship between business ethics perceptions and extraversion. No support was found for extraversion. Past research examining the relationship between extraversion and ethical behavior in an academic setting has yielded weak and conflicting results (Williams et al., 2010). Cizek (1999) found that in three of four studies that examined this relationship, extraversion was positively related to cheating behavior. Bushway and Nash (1977) also found that extraversion was related to cheating behavior. However, Jackson et al. (2002) found that extraversion was not related to cheating behavior. Our results here are consistent with the results observed by Jackson et al. (2002) in past research. Although we theorized that the positive affect component of extraversion would produce a positive relationship with ethical perceptions, it is important to note that positive affect is merely one facet of extraversion. Extraversion also includes gregariousness, assertiveness, energy and excitementseeking (Piedmont, 1998). Although some research has linked extraversion to empathy (del Barrio, Aluja, \& Garcia, 2004) and cognition (Stafford, Ng, Moore, \& Bard, 2010), there is also research that found extraversion to be negatively linked to integrity (Marcus, Lee, \& Ashton, 2007) and positively linked to aggression (Egan \& Lewis, 2011). It may be that the assertiveness facets of this trait countered its positive emotion facets and neutralized the impact of extraversion on ethics perceptions in this study.

We found support for Hypothesis 3, that conscientious individuals would be more likely to make ethical business decisions. This result is consistent with past research in both an academic setting (Emler, 1999; Kisamore et al., 2007; Murphy, 2000; Williams et al., 2010) and a business setting (Hogan \& Hogan, 1989; Kalshoven et al., 2011). This research highlights the importance of conscientious employees in the workplace. Not only are these employees motivated, responsible, and organized (Costa \& McCrae, 1992), but because of these traits conscientious employees often avoid situations that would even give rise to unethical behavior. The link between conscientiousness and academic preparedness makes the relationship more salient in the context of academic honesty. Recent research suggests that, once an individual forms the attitude that cheating is an acceptable behavior, she or he will be more likely to engage in cheating behavior 
in other contexts (Nonis \& Swift, 2002). This further highlights the importance of cultivating conscientious individuals in an academic setting and its implications for future ethical behavior and decisions in business.

Hypothesis 4 states that academic honesty would positively relate to business ethics. Consistent with past research (Bernardi et al., 2004; Lawson, 2004; Nonis \& Swift, 2001; White \& Dooley, 1993), this hypothesis was supported. There is a strong positive relationship between student attitudes toward academic honesty and business ethics. This underscores the importance of the role of educators and business educators in particular in enforcing rules and expectations for honesty in an academic setting.

A key contribution of our study was the (partial) mediating role of academic honesty between conscientiousness and business ethics. This relationship is certainly consistent with the research cited in discussing the results for Hypothesis 4. But it also highlights the significance of academic honesty and its role in the black box of ethical decision-making research. Drawing on the theory of meaningful work (Barrick et al., 2013), this study provides some clarification as to why the academic context seems to resonate more with students over workplace scenarios: The academic context is more meaningful to students and therefore the ethical dilemmas presented within that context have a higher degree of moral intensity (Jones, 1991). There is a pattern of research that has suggested that business students cheat more in academic settings. Bernardi et al. (2004) found that business majors scored lower on moral development than students from other majors. Others (Meade, 1992; Park, 2003; Pullen et al, 2000) have found that business students engage in cheating behavior in an academic context more than any other major. Further, research has indicated that student attitudes toward unethical behavior formed in an academic context have a lasting impact on their future ethical behavior in a business context (Elias \& Kim, 2004; Lawson, 2004; Nonis \& Swift, 2003; Sims, 1993). It is logical to expect that the best predictor of future behavior is past behavior. This finding suggests that managers may need to assess prospective employees about past cheating behavior to get a good measure of how these employees will behave in future ethical situations that they may encounter on the job. This finding also suggests that business practitioners need to find a way to emphasize the meaningfulness of ethical dilemmas that may arise within a given work environment. Educating employees on common ethical dilemmas so as to highlight the moral intensity of these issues may be a logical starting place. Finally, this finding indicates that business educators may have more success in producing ethical graduates by focusing on the development of academically honest behaviors among their more conscientious students.

\section{Limitations and Strengths}

This research makes meaningful contributions to this field of study, but there were some limitations. This study was based on cross-sectional data; thus, it was not possible to test the directionality of the hypothesized relationships. In addition, an experimental design involving a business ethics simulation would have increased the validity of our measurement of business ethics. A final limitation of this research lies in the use of self-report survey measures which causes our research to be vulnerable to the possible biasing impact of common methods.

This study also had several strengths. Several previous studies (e.g., Barrett \& Cox, 2005; Yeo, 2007) used single-item measures to assess plagiarism perceptions. This study follows the 
work of Jung (2009) and Yang (2012) by applying a validated approach to measuring business ethics perceptions, the MES (Reidenbach \& Robin, 1990), to the context of plagiarism. Using the MES, we can gain insight as to how and why students make the choices they do in academic ethical dilemmas. Second, this study addresses a gap in the literature by applying one of most researched personality profiles in management and psychology research to academic honesty and business ethics. As noted by Williams et al. (2010), given the consensus of the importance of the Big 5 personality traits, it is surprising how few studies have examined the relationship between these personality traits and academic honesty. This study answers this call by examining the impact of neuroticism, extraversion, and conscientiousness on perceptions of academic honesty and business ethics. Finally, this research advances the academic honesty and business ethics literature streams. By combining these research streams, we were able to more clearly investigate the importance of academic honesty in predicting business ethics attitudes. Using this lens, we are able to offer some very practical advice to employers and educators seeking to improve business ethical behavior among future employees, and this may stimulate further empirical investigations into the mediating role of academic honesty between other personality variables and business ethics.

\section{Implications for Practice and Future Research}

The study of business ethics and ethical decision making is rife with methodological challenges and mixed findings indicate that the influence of context may be the most significant determinant of ethical behavior (Bratton, 2004; McCabe, Trevino, \& Butterfield, 2002). Our findings suggest that the most significant influence on ethical decisions in business may be the environment in which business practitioners are trained. Students who perceive that academic dishonesty is acceptable similarly tolerate unethical behavior in a business context. This study suggests that the answer to the question posed in this article title, "To cheat or not to cheat?" is, "It depends on how conscientious she or he is and how she or he was trained."

These findings provide strong encouragement to managers to identify the prospective employees who demonstrate conscientiousness and concern for ethical behavior in an academic context. Further, it highlights the importance of the role of educators in creating an environment that clearly states behavioral expectations in regards to academic honesty and consistently punishes instances of dishonesty. Faculty and administration in a higher education setting are paramount in preventing academic dishonesty as well as future unethical behavior in the workplace. Faculty members must work to engage students in assignments and discourage unethical behavior in the classroom. Administrators must establish and enforce honor codes so that all college constituents understand the consequences of academic dishonesty (McCabe et al., 2002). By consistently responding to every incident of academic dishonesty, educators are training students to respect ethical behavior guidelines. Students are also conditioned to perceive infractions of ethical behavior guidelines to be incidents of increased moral intensity that will stimulate mindful behavioral responses to potential ethical dilemmas in academic settings, which research has shown follow them into the workplace (Lawson, 2004; Nonis \& Swift, 2001).

Empirical findings that elucidate the role that academic honesty plays on future business ethical behavior are significant for both researchers and practitioners. For instance, one may want to further investigate the impacts that the Big 5 personality profile (including Agreeableness and 
Openness to Experience as well as Neuroticism, Extroversion, and Conscientiousness) may have on academic and business ethics. One may also seek to integrate a measure of moral intensity into future investigations in order to determine its impact on perception of ethics in differing scenarios and contexts. Moreover, we encourage the use of behavioral simulations to capture measures of academic ethical behavior rather than survey assessments of the perceptions thereof. Finally, we advocate a longitudinal study design where measures of business ethics perceptions can be assessed well after measures of academic honesty are taken to be able to determine causality. We hope that this study will encourage other scholars to continue integrating these fields of study. By joining the research streams in academic and business ethics, we will be better able to comprehend the multifaceted nature of the impact that disposition and ethics training has on ethical performance in the workplace.

In conclusion, this research underscores the significance of applying Big 5 personality dimensions to the context of academic and business ethics, as well as further exploring the nature of the relationship between academic honesty and business ethics perceptions. Our results suggest key consequences for business practitioners who are accountable for promoting ethical behavior in the workplace. Moreover, our results may offer management scholars new insight on the link between disposition and academic honesty, as well as their influence on business ethics perceptions.

\section{REFERENCES}

Ajzen, I. (1991). The theory of planned behavior. Organizational Behavior and Human Decision Processes, 50, $179-211$. doi:10.1016/0749-5978(91)90020-T

Angelidis, J., \& Ibrahim, N. A. (2011). The impact of emotional intelligence on the ethical judgment of managers. Journal of Business Ethics, 99, 111-119. doi: http://dx.doi.org/10.1007/s10551-011-1158-5

Atashrouz, B., Pakdaman, S., \& Asgari, A. (2008). The relationship between the big five personality traits and academic achievement. Journal of Iranian Psychologists, 4, 367-376. Retrieved from http://search.proquest.com/docview/ 621691214 ? accountid $=28148$

Baron, R. M., \& Kenny, D. A. (1986). The moderator-mediator variable distinction in social psychological research: Conceptual, strategic and statistical considerations. Journal of Personality and Social Psychology, 51, 1173-1182. Retrieved from APA PsychArticles.

Barrett, R., \& Cox, A. L. (2005). "At least they're learning something”: The hazy line between collaboration and collusion. Assessment and Evaluation in Higher Education, 30, 107-122. doi:10.1080/0260293042000 264226

Barrick, M. R., \& Mount, M. K. (1991). The big five personality dimensions and job performance: A meta-analysis. Personnel Psychology, 44, 1-46. Retrieved from Academic Search Complete.

Barrick, M. R., Mount, M. K., \& Li, N. (2013). The theory of purposeful work behavior: The role of personality, higherorder goals and job characteristics. Academy of Management Review, 38, 132-153. doi:10.5465/amr.2010.0479

Bernardi, R. A., Metzger, R. L., Bruno, R., Hoogkamp, M., Reyes, L. E., \& Barnaby, G. H. (2004). Examining the decision process of students' cheating behavior: An empirical study. Journal of Business Ethics, 50, 397-414. doi:10.1023/B: BUSI.0000025039.47788.c2

Berry, C. M., Ones, D. S., \& Sackett, P. R. (2007). Interpersonal deviance, organizational deviance, and their common correlates: A review and meta-analysis. Journal of Applied Psychology, 92, 410-424. doi:10.1037/0021-9010.92.2.410

Bloodgood, J. M., Turnley, W. H., \& Mudrack, P. E. (2010). Ethics instruction and the perceived acceptability of cheating. Journal of Business Ethics, 95, 23-37. doi:10.1007/s10551-009-0345-0

Bono, J. E., \& Judge, T. A. (2000). Five-factor model of personality and transformational leadership. Journal of Applied Psychology, 85, 751-765. doi:10.1080/0260293042000264226

Bratton, V. K. (2004). Affective morality: the role of emotions in the ethical decision-making process (Unpublished doctoral dissertation). Florida State University, Tallahassee. 
Brown, T. A., Sautter, J. A., Littvay, L., Sautter, A. C., \& Bearnes, B. (2010). Ethics and personality: Empathy and narcissism as moderators of ethical decision making in business students. Journal of Education for Business, 85, 203-208. doi:10.1080/08832320903449501

Busato, V. V., Prins, F. J., Elshout, J. J., \& Hamaker, C. (1999). The relation between learning styles, the big five personality traits and achievement motivation in higher education. Personality and Individual Differences, 26, 129-140. doi:10.1016/S0191-8869(98)00112-3

Bushway, A., \& Nash, W. R. (1977). School cheating behavior. Review of Educational Research, 47, $623-632$. doi:10.3102/00346543047004623

Cizek, G. J. (1999). Cheating on tests: How to do it, detect it, and prevent it. Mahwah, NJ: Erlbaum.

Clark, M. H., \& Schroth, C. A. (2010). Examining relationships between academic motivation and personality among college students. Learning and Individual Differences, 20, 19-24. doi:10.1016/j.lindif.2009.10.002

Collins, D. (2000). The quest to improve the human condition: The first 1, 500 articles published in Journal of Business Ethics. Journal of Business Ethics, 26, 1-73. doi:10.1023/A:1006358104098

Costa, P., Jr., \& McCrae, R. R. (1992). The revised NEO personality inventory (NEOPI-R) and NEO Five-Factor inventory (NEO-FFI) professional manual. Odessa, FL: Psychological Assessment Resources.

Cruz, C. A., Shafer, W. E., \& Strawser, J. R. (2000). A multidimensional analysis of tax practitioner's ethical judgments. Journal of Business Ethics, 24, 223-244. doi:10.1023/A:1006140809998

de Bruin, G. P., \& Rudnick, H. (2007). Examining the cheats: The role of conscientiousness and excitement seeking in academic dishonesty. South African Journal of Psychology, 37, 153-164. Retrieved from Academic Search Complete.

de Feyter, T., Caers, R., Vigna, C., \& Berings, D. (2012). Unraveling the impact of the big five personality traits on academic performance: The moderating and mediating effects of self-efficacy and academic motivation. Learning and Individual Differences, 22, 439-448. doi:10.1016/j.lindif.2012.03.013

Del Barrio, V., Aluja, A., \& Garcia, L. F. (2004). Relationship between empathy and the big five personality traits in a sample of Spanish adolescents. Social Behavior and Personality, 32, 677-682. doi: 10.2224/sbp.2004.32.7.677

Detert, J. R., Treviño, L. K., \& Sweitzer, V. L. (2008). Moral disengagement in ethical decision making: A study of antecedents and outcomes. Journal of Applied Psychology, 93, 374-391. doi:10.1037/0021-9010.93.2.37

DuPont, A. M. \& Craig, J. S. (1996). Does management experience change the ethical perceptions of retail professionals: A comparison of the ethical perceptions of current students with those of recent graduates? Journal of Business Ethics, 15, 815-826. doi:10.1007/BF00381850

Egan, V., \& Lewis, M. (2011). Neuroticism and agreeableness differentiate emotional and narcissistic expressions of aggression. Personality and Individual Differences, 50, 845-850. doi: 10.1016/j.paid.2011.01.007

Elias, R. Z., \& Kim, N. J. (2005). The relationship between accounting students' perceptions of cheating and questionable workplace behavior. Central Business Review, 24, 16-19. doi:10.1007/s10805-011-9144-1

Emler, N. (1999). Moral character. In V. J. Derlaga, B. A. Winstead, \& W. H. Jones (Eds.), Personality: Contemporary theory and research (pp. 377-404). Chicago, IL: Nelson-Hall.

Flory, S. M., Phillips, T. J., Reidenbach, R. E., \& Robin, D. P. (1992). A multidimensional analysis of selected ethical issues in accounting. The Accounting Review, 67, 284-302. Retrieved from http://www.jstor.org/stable/247725

Ford, R. C., \& Richardson, W. D. (1994). Ethical decision making: A review of the empirical literature. Journal of Business Ethics, 13, 205-221. doi:10.1007/BF02074820

Forgas, J. P. (Ed.). (2001). Handbook of affect and social cognition. Hillsdale, NJ: Erlbaum.

Forte, A. (2005). Locus of control and the moral reasoning of managers. Journal of Business Ethics, 58, 65-77. doi:10.1007/s10551-005-1387-6

Gale, A., Edwards, J., Morris, P., Moore, R., \& Forrester, D. (2001). Extraversion-introversion, neuroticism-stability, and EEG indicators of positive and negative empathic mood. Personality \& Individual Differences, 30, 449-461. doi:10.1016/S0191-8869(00)00036-2

Gray, J. A. (1990). Brain systems that mediate both emotion and cognition. Motivation and Emotion, 4, $269-288$. doi:10.1080/02699939008410799

Gray, J. A. (1994). Personality dimensions and emotion systems. In P. Ekman \& R. J. Davidson (Eds.), The nature of emotion: Fundamental questions (pp. 329-331). New York, NY: Oxford University Press.

Hackman, J. R., \& Oldham, G. R. (1975). Development of job diagnostic survey. Journal of Applied Psychology, 55, 159-170. doi:10.1037/h0076546

Hegarty, W. H., \& Sims, H. P. (1978). Some determinants of unethical decision behavior: An experiment. Journal of Applied Psychology, 63, 451-457. doi:10.1037/0021-9010.63.4.451: 
Higgins, D. M., Peterson, J. B., Pihl, R. O., \& Lee, A. G. M. (2007). Prefrontal cognitive ability, intelligence, Big Five personality, and the prediction of advanced academic and workplace performance. Journal of Personality and Social Psychology, 93, 298-319. doi:10.1037/0022-3514.93.2.298

Hochwarter, W. A., Witt, L. A., \& Kacmar, K. M. (2000). Perceptions of organizational politics as a moderator of the relationship between conscientiousness and job performance. Journal of Applied Psychology, 85, 472-478. doi:10.1037//0021-9010.85.3.472

Hogan, R., \& Hogan, J. (1989). How to measure employee reliability. Journal of Applied Psychology, 74, $273-279$. Retrieved from APA PsychArticles.

Hudson, S., \& Miller, G. (2005). Ethical orientation and awareness of tourism students. Journal of Business Ethics, 62, 383-396. doi:10.1007/s10551-005-0850-8

Hume, E. C., \& Smith, A. (2006). University student ethics: The differential explanatory effect of locus of control. Academy of Educational Leadership Journal, 10, 49-58. Retrieved from Academic OneFile

Jackson, C. J., Levine, S. Z., Furnham, A., \& Burr, N. (2002). Predictors of cheating behavior at a university: A lesson from the psychology of work. Journal of Applied Social Psychology, 32, 1031-1046. doi:10.1111/j.15591816.2002.tb00254.x

Jones, T. M. (1991). Ethical decision making by individuals in organizations: An issue-contingent model. Academy of Management Review, 16, 366-395. Retrieved from http://www.jstor.org/stable/258867

Joseph, J., Berry, K., \& Deshpande, S. P. (2009). Impact of emotional intelligence and other factors on perception of ethical behavior of peers. Journal of Business Ethics, 89, 539-546. doi:10.1007/s10551-008-0015-7

Judge, T. A., Heller, D., \& Mount, M. K. (2002). Five-factor model of personality and job satisfaction. Journal of Applied Psychology, 87, 530-541. doi:10.1037//0021-9010.87.3.530

Jung, I. (2009). Ethical judgments and behaviors: Applying a multidimensional ethics scale to measuring ICT ethics of college students. Computers and Education, 53, 940-949. doi:10.1016/j.compedu.2009.05.011

Kalshoven, K., Den Hartog, D. N., \& De Hoogh, A. H. B. (2011). Ethical leader behavior and big five factors of personality. Journal of Business Ethics, 10, 349-366. doi:10.1007/s10551-010-0685-9

Karim, N. S. A., Zamzuri, N. H. A., \& Nor, Y. M. (2009). Exploring the relationship between internet ethics in university students and the Big Five model of personality. Computers \& Education, 53, 86-93. doi:10.1016/j.compedu.2009.01.001

Kets de Vries, M. F. R. (1984). The neurotic organization: Diagnosing and changing counterproductive styles of management. San Francisco, CA: Jossey Bass.

Kisamore, J. L., Stone, T. H., \& Jawahar, I. M. (2007). Academic integrity: The relationship between individual and situational factors on misconduct contemplations. Journal of Business Ethics, 75, 381-394. doi:10.1007/s10551-0069260-9

Komarraju, M., \& Karau, S. J. (2005). The relationship between the big five personality traits and academic motivation. Personality and Individual Differences, 39, 557-567. doi:10.1016/j.paid.2005.02.013

Komarraju, M., Karau, S. J., Schmeck, R. R., \& Avdic, A. (2011). The big five personality traits, learning styles, and academic achievement. Personality and Individual Differences, 51, 472-477. doi:10.1016/j.paid.2011.04.019

Kumar, K., Bakhshi, A., \& Rani, E. (2009). Linking the big five personality domains to organizational citizenship behavior. International Journal of Psychological Studies, 1, 73-81. Retrieved from http://www.ccsenet.org/journal/index. php/ijps/article/view/2593/3835

Larsen, R. J. (2000). Toward a science of mood regulation. Psychological Inquiry, 11, 129-141. Retrieved from http:// www.jstor.org/stable/1449791

Larsen, R. J., \& Ketelaar, T. (1989). Extraversion, neuroticism, and susceptibility to positive and negative emotional states. Personality and Individual Differences, 10, 1221-1228. Retrieved from ScienceDirect.

Lawson, R. A. (2004). Is classroom cheating related to business students' propensity to cheat in the "real world"? Journal of Business Ethics, 49, 189-199. doi:10.1023/B: BUSI.0000015784.34148.cb

Loe, T. W., Ferrell, L., \& Mansfield, P. (2000). A review of empirical studies assessing ethical decision making in business. Journal of Business Ethics, 25, 185-204. doi:10.1023/A:1006083612239

Marcus, B., Lee, K., \& Ashton, M. C. (2007). Personality dimensions explaining relationships between integrity tests and counterproductive behavior: Big Five, or one in addition? Personnel Psychology, 60, 1-34. doi:10.1111/j.17446570.2007.00063.x

Mathisen, G., Einarsen, S., \& Mykletun, R. (2011). The relationship between supervisor personality, supervisors' perceived stress and workplace bullying. Journal of Business Ethics, 99, 637-651. doi:10.1007/s10551-010-0674-Z 
McCabe, D. L., Butterfield, K. D., \& Trevino, L. K. (2006). Academic dishonesty in graduate business programs: Prevalence, causes, and proposed action. Academy of Management Learning \& Education, 5, $294-305$. doi:10.5465/AMLE.2006.22697018

McCabe, D. L., Trevino, L. K., \& Butterfield, K. D. (2002). Honor codes and other contextual influences on academic integrity: A replication and extension to modified honor code settings. Research in Higher Education, 43, 357-378. Retrieved from SpringerLink.

Meade, J. (1992). Cheating is academic dishonesty par for the course. Prism, 1, 30-32.

Megehee, C. M., \& Spake, D. F. (2008). The impact of perceived peer behavior, probable detection and punishment severity on student cheating behavior. Marketing Education Review, 18, 5-19 Retrieved from Business Source Complete.

Moberg, D. J. (1999). The big five and organizational virtue. Business Ethics Quarterly, 9, 245-272. Retrieved from http://www.jstor.org/stable/3857474

Mudrack, P. E., \& Mason, E. S. (1995). More on the acceptability of workplace behaviors of a dubious ethical nature. Psychological Reports, 76, 639-648. doi:10.2466/pr0.1995.76.2.639

Murphy, K. R. (2000). What constructs underlie measures of honesty or integrity? In R. D. Goffin \& E. Helmes (Eds.), Problems and solutions in human assessment: Honoring Douglas N. Jackson at seventy (pp. 265-283). New York, NY: Kluwer Academic/Plenum.

Nathanson, C., Paulhus, D. L., \& Wiliams, K. M. (2006). Predictors of a behavioral measure of scholastic cheating: Personality and competence but not demographics. Contemporary Educational Psychology, 31, 97-122. doi:10.1016/j.cedpsych.2005.03.001

Nonis, S., \& Swift, C. O. (2001). An examination of the relationship between academic dishonesty and workplace dishonesty: A multicampus investigation. Journal of Education for Business, 77, 69-77. doi:10.1080/08832320109599052

O'Connor, M. C., \& Paunonen, S. V. (2007). Big five personality predictors of post-secondary academic performance. Personality and Individual Differences, 43, 971-990. doi:10.1016/j.paid.2007.03.017

Organ, D. W. (1994). Personality and organizational citizenship behavior. Journal of Management, $20,465-478$. doi:10.1016/0149-2063(94)90023-X

Park, C. (2003). In other (people's) words: Plagiarism by university students-literature and lessons. Assessment \& Evaluation in Higher Education, 28, 471-488. doi:10.1080/02602930301677

Perrewé, P. L., \& Spector, P. E. (2002). Personality research in the organizational sciences. In G. R. Ferris (Ed.), Research in personnel and human resources management (pp. 1-63). Oxford, UK: JAI Press/Elsevier Science.

Piedmont, R. L. (1998). The Revised NEO Personality Inventory: Clinical and research applications. New York, NY: Plenum.

Pullen, R., Ortloff, V., Casey, S., \& Payne, J. B. (2000). Analysis of academic misconduct using unobtrusive research: A study of discarded cheat sheets. College Student Journal, 34, 616-625. Retrieved from Academic Search Complete.

Rakovski, C. C., \& Levy, E. S. (2007). Academic dishonesty: Perceptions of business students. College Student Journal, 41, 466-481. Retrieved from Academic Search Complete.

Reed, M. B., Bruch, M. A., \& Haase, R. F. (2004). Five-factor model of personality and career exploration. Journal of Career Assessment, 12, 223-238. doi:10.1177/1069072703261524

Reidenbach, R. E., \& Robin, D. P. (1990). Toward the development of a multidimensional scale for improving evaluations of business ethics. Journal of Business Ethics, 9, 639-653. doi:10.1007/BF00383391

Rest, J. R. (1986). Moral development. New York, NY: Praeger.

Rest, J. R., \& Narvaez, D. (1994). Moral development in the professions: Psychology and applied ethics. Hillsdale, NJ: Erlbaum.

Robin, D., \& Babin, L. (1997). Making sense of the research on gender and ethics in business: A critical analysis and extension. Business Ethics Quarterly, 7, 61-90. Retrieved from http://www.jstor.org/stable/3857209

Sautter, J. A., Brown, T. A., Littvay, L., Sautter, A. C., \& Bearnes, B. (2008). Attitude and divergence in business students: An examination of personality differences in business and non-business students. Electronic Journal of Business Ethics and Organization Studies, 13, 70-78. Retrieved from http://search.proquest.com/docview/ 621838212 ? accountid $=28148$

Seibert, S. E., \& Kraimer, M. L. (2001). The five-factor model of personality and career success. Journal of Vocational Behavior, 58, 1-21. doi:10.1006/jvbe.2000.1757

Shi, J., Xu, X., \& Yu, F. (2011). Ethical leadership and leaders' personalities. Social Behavior and Personality: An International Journal, 39, 361-368. doi:10.2224/sbp.2011.39.3.361 
Sims, R. L. (1993). The relationship between academic dishonesty and unethical business practices. Journal of Education for Business, 68, 207-211. doi:10.1080/08832323.1993.10117614

Singhapakdi, A., Vitell, S. J., \& Franke, G. R. (1999). Antecedents, consequences, and mediating effects of perceived moral intensity and personal moral philosophies. Journal of the Academy of Marketing Science, 27, 19-36. doi:10.1177/0092070399271002

Smyth, M. L., \& Davis, R. J. (2004). Perceptions of dishonesty among two-year college students: Academic versus business situation. Journal of Business Ethics, 51, 63-73. doi:10.1023/B: BUSI.0000032347.79241.3c

Stafford, L., Ng, W., Moore, R., \& Bard, K. (2010). Bolder, happier, smarter: The role of extraversion in positive mood and cognition. Personality and Individual Differences, 48. 827-832. doi:10.1016/j.paid.2010.02.005

Tang, T. L., \& Chen, Y. (2008). Intelligence vs. wisdom: The love of money, machiavellianism, and unethical behavior across college major and gender. Journal of Business Ethics, 82, 1-26. doi:10.1007/s10551-007-9559-1

Waples, E. P., Antes, A. L., Murphy, S. T., Connelly, S., \& Mumford, M. D. (2009). A meta-analytic investigation of business ethics instruction. Journal of Business Ethics, 87, 133-151. doi:10.1007/s10551-008-9875-0

White, C. S., \& Dooley, R. S. (1993). Ethical or practical: An empirical study of students' choices in simulated business scenarios. Journal of Business Ethics, 12, 643-651. doi:10.1007/BF01845903

Williams, K. M., Nathanson, C., \& Paulhus, D. L. (2010). Identifying and profiling scholastic cheaters. Journal of Experimental Psychology Applied, 16, 293-307. Retrieved from APA PsychArticles.

Yang, S. C. (2012). Ethical academic judgments and behaviors: Applying the Multidimensional Ethics Scale to measure the ethical academic behavior of graduate students. Ethics \& Behavior, 22, 281-296. doi:10.1080/10508422.2012.672907

Yeo, S. (2007). First-year university science and engineering students' understanding of plagiarism. Higher Education Research and Development, 26, 199-216. doi:10.1080/07294360701310813

Zhang, L. (2003). Does the Big Five predict learning approaches? Personality and Individual Differences, 34, 1431-1446. doi:10.1016/S0191-8869(02)00125-3 